https://helda.helsinki.fi

Professional non-neutrality: criticising the third party in psychotherapy

\author{
Voutilainen, Liisa
}

2010

Voutilainen , L , Peräkylä , A \& Ruusuvuori , J E 2010 , ' Professional non-neutrality:

criticising the third party in psychotherapy ' , Sociology of Health \& Illness , vol. 32 , no. 5 , pp. 798-816 . https://doi.org/10.1111/j.1467-9566.2010.01245.x

http://hdl.handle.net/10138/29484

https://doi.org/10.1111/j.1467-9566.2010.01245.x

publishedVersion

Downloaded from Helda, University of Helsinki institutional repository.

This is an electronic reprint of the original article.

This reprint may differ from the original in pagination and typographic detail.

Please cite the original version. 


\section{Professional non-neutrality: criticising the third party in psychotherapy}

\section{Liisa Voutilainen', Anssi Peräkylä ${ }^{2}$ and Johanna Ruusuvuori ${ }^{3}$}

${ }^{1}$ Department of Social Research, University of Helsinki, Finland

${ }^{2}$ Collegium for Advanced Studies, University of Helsinki, Finland

${ }^{3}$ Department of Social Research, University of Tampere, Finland

Abstract Using audio-recorded data from cognitive-constructivist psychotherapy, the article shows a particular institutional context in which successful professional action does not adhere to the pattern of affective neutrality which Parsons saw as an inherent component of medicine and psychotherapy. In our data, the professional's non-neutrality functions as a tool for achieving institutional goals. The analysis focuses on the psychotherapist's actions that convey a critical stance towards a third party with whom the patient has experienced problems. The data analysis revealed two practices of this kind of critique: (1) the therapist can confirm the critique that the patient has expressed or (2) return to the critique from which the patient has focused away. These actions are shown to build grounds for the therapist's further actions that challenge the patient's dysfunctional beliefs. The article suggests that in the case of psychotherapy, actions that as such might be seen as apparent lapses from the neutral professional role can in their specific context perform the task of the institution at hand.

Keywords: psychotherapy, professional neutrality, institutional interaction, conversation analysis

\section{Introduction}

Following Parsons (1951), modern professional behaviour is typically characterised by affective neutrality. As a value orientation of the participants, affective neutrality structures institutional social relations, and thus is a component of social order. Parsons held affective neutrality to be particularly important for the physician's (and psychotherapist's) role: it enables the professional to enter the patient's private affairs without launching a personal reciprocal relationship and maintains the professional's objective role. As Parsons (1951: 461) puts it, the physician and the psychotherapist alike, "refuse[s] to be "drawn in" to an emotionally reciprocal relationship with the patient. Medicine as a social system provides 'institutional backing' (1951: 46) for this refusal. In more general terms of the social system, affective neutrality enables the professional's functioning as a gatekeeper between normal and deviant, between health and illness. The idea of the professional's role that distances itself from the patient's affairs has remained viable since Parson's time, whilst dichotomy 
between affectivity and affective neutrality has been broken down by such concepts as detached concern (Fox 1979, Bershady 2005: 89), caring (Macdonald 1995: 137) or empathy (Rogers 1957).

The question of professional neutrality has been approached empirically in the study of institutional interaction. Drew and Heritage (1992: 47) suggest that the professional participants in institutional interactions design their talk so as to maintain a cautiousness, or even a position of neutrality with respect to their co-participants'. Conversation analytical studies offer ample evidence for this, by showing the ways in which the professional parties in various types of institutional interaction withhold from overtly affiliating or disaffiliating actions vis-à-vis their clients, and avoid taking a stance towards the matters that they deal with. For example, the 'formal turn-taking system' in news interviews puts the interviewer into a position where $\mathrm{s}$ /he can only ask questions, not for example give assessments (Greatbatch 1992); the regulation of the 'production format' of a question or a statement (to specify who actually is behind the words that are spoken) serves as a resource for journalists or mediators to maintain a 'neutralistic' position even when they are, in fact, conveying controversial materials (Garcia 1991, Clayman 1992, Heisterkamp 2006); psychiatrists in intake interviews 'design their descriptions' using negations (rather than assertions) and mitigations so as to avoid overtly asserting that the patient is mentally ill (Bergmann 1992); and mediators in small claims can 'paraphrase' the client's utterances in a manner that carefully and manifestly reflects the original presentation without taking a stance towards it (Heisterkamp 2006).

However, empirical studies on institutional interaction have also shown some cases that are not fully in line with the Parsonian thesis regarding the professional's affective neutrality. In these cases, the professionals act in non-neutral ways, and the clients orient towards the professional actions as non-neutral. On the one hand, this involves professionals' 'initiatory actions' such as questions, which can carry a wide variety of accusatory, critical, diagnostic or other non-neutral implications or presuppositions, for example in legal (Drew 1992), journalistic (Clayman and Heritage 2002) or psychotherapeutic (Peräkylä 1995, Halonen 2006, MacMartin 2008) settings. On the other hand - and this concerns us more in this paper - the professionals' non-neutrality may reside in their responsive actions. Ruusuvuori (2005 and 2007) has examined the ways in which professionals in general practice and homeopathy often receive the patients' troubles tellings in affiliating (and thus non-neutral) ways, either through affiliating relevant response parts or through extended utterances in which they convey that they understand the patient's plight. This affiliation, however, is ordinarily shortlived as it works 'towards the closure of the sequence of troubles-telling and shifting back to [medical] problem-solving activity' (Ruusuvuori 2007: 598).

So, even though neutrality seems to characterise many aspects of institutional interaction, it is not pervasive. There are types of institutional interaction (such as cross-examination (Drew 1992) that are arguably thoroughly non-neutral. And there are 'pockets of nonneutrality' of professional action in settings, such as medicine, that might otherwise be characterised by neutrality.

In this paper, we will explore a specific pocket of non-neutrality in psychotherapeutic interaction by examining the professional's responsive actions. More specifically, we will explore the ways in which a psychotherapist, in receiving an utterance where her patient has criticised a third party, displays alliance with the patient against this third party.

Before presenting our data analysis, a brief account of 'neutrality' in psychotherapy theory is due. Since psychotherapy as professional practice started at the turn of the $20^{\text {th }}$ century, the therapist's neutrality has been a part of its professional ideology. For Freud, the key idea in this respect was the therapist's abstinence (Freud 1915): the therapist was to withhold from responding to the patient's wishes and demands, and to avoid fulfilling the roles that the 
patient tended to impose upon him or her (see also Lapanche and Pontalis 1973: 2-3, Sandler et al. 1992: 16). Parsons indeed was thoroughly aware of this classical Freudian understanding of abstinence, and he used it as a resource in formulating his thesis on professional affective neutrality (see Parsons 1951: 460-2).

During the $20^{\text {th }}$ century, however, the very term 'neutrality' seems to have been contested in the psychoanalytic movement. There was a long debate regarding the ways in which the therapist should indeed or should not be neutral (see e.g. Greenberg 1986). 'Pure' neutrality was often seen as impossible and/or dysfunctional, and an attitude of benign understanding was regarded as a necessary counterweight to neutrality (see Moore and Fine 1990: 127). In an often-cited textbook on psychoanalytic method, Greenson (1967: 281) gives a crisp account of this dual task of the therapist. To safeguard the psychoanalytic process (the transference), the therapist has to maintain his or her 'anonymity and deprivational attitude' toward the patient's wishes. But at the same time, to safeguard the working alliance with the patient, the therapist has to 'behave in a humane way'.

In contrast to psychoanalysis, the issues of the therapist's affective stance are not central to the literature of cognitive therapies (Kimerling et al. 2000: 313, Safran and Segal 1990: 25-9). There is, however, also a tension between benign understanding and neutrality which seems to crop up here. In classical cognitive therapy, neutrality is not emphasised, as the therapists are advised in general terms to be warm, genuine and empathetic in order to develop a collaborative relationship with the patients (Beck et al. 1979). But in a more recent, interpersonal approach of cognitive therapy, the therapists are advised to recognise the stance that the patient invites from the therapist and to resist taking this stance (e.g. reassuring the patient) in case it would confirm what the therapist defines as the patient's generalised, dysfunctional representations of interaction with others (Safran and Segal 1990).

At some points of the therapeutic interaction, the principles of neutrality (or resisting patient's invitations) and expressing empathy may give rise to a dilemma. One such instance is when the patient complains about other people's conduct. A typical therapeutic solution would probably be to explicitly focus on the patients' experience and not to comment on the conduct of the third party as such (Bergmann 2008). In this solution, the therapist would indeed resist taking the stance or role that the patient is inviting him or her to take (Safran and Segal 1990, Freud 1915) and thus maintain a specific form of neutrality. In this paper we will however look at responses that do not follow this strategy. We will show how responses that ally with the patient against a 'third party' are used in one therapeutic setting, namely cognitive-constructivist therapy.

The therapeutic orientation in question is a 'post-rationalistic' type of cognitive therapy, emphasising subjective meanings and emotions besides questioning the rationality of cognitions (see e.g. Guidano 1991). The data of the study consist of audio-recordings of therapy sessions of one therapist and one patient from a time period of 18 months. From a corpus of 57 sessions approximately 20 hours have been transcribed (some sessions wholly and some partly). As the study focuses on interaction in an individual therapy process, the practices that are presented in this paper cannot be described as typical for cognitiveconstructivist therapy. They might be the therapist's specific ways to work in this particular therapy process with a patient who has a tendency to react with self-blame when other people have been insulting to her: this theme was recurrently discussed in the therapy, and the therapist has confirmed to the first author that a core belief that was worked on in this therapy had to do with seeing oneself as liable to mistreatment by others. However, our analysis shows possible ways in which the therapist can use resources of interaction to carry out therapeutic work (see Peräkylä 2004a). In the analysis of the data we use conversation analysis (Schegloff 2007, see also Peräkylä 2004b) and especially the applications of 
conversation analysis that belong to the study of institutional interaction (Drew and Heritage 1992, Arminen 2005).

The therapists' contributions that we look at in this paper are responsive actions (Schegloff 2007, Vehviläinen et al. 2008) to the patient's descriptions about her experience or about the conduct of a third party. Previous conversation analytic studies on therapeutic interaction have described responsive actions that reformulate the patient's preceding talk, or interpret the patient's mind (e.g. Antaki et al. 2005, Vehviläinen 2003, Peräkylä 2004c, Bercelli et al. 2008). The therapist's contributions that are the focus of this paper have features of these actions, but they also contain another kind of feature: they make statements about a state of affairs in the 'outer reality' by critically commenting on the conduct of a third party whom the patient has presented as problematic for her. In this respect, these actions have similarities with what has been reported on affiliation with troubles-telling (e.g. Jefferson 1988, Ruusuvuori 2007) and complaints (e.g. Drew and Walker 2009, Ruusuvuori and Lindfors 2009) in everyday talk and institutions.

\section{Focus of the analysis}

In the sequences in focus, the patient describes her negative experiences in relation to a person close to her, and the therapist responds to this description. The patient's descriptions of her experiences resemble complaining in the sense that they often present the patient as not having been appropriately treated by the third party in question, and in this way imply a negative stance towards this third party (see Günthner 1997, Haakana 2007). However, this negative stance is often only embedded in the patient's description of her own negative experiences - her contributions are not primarily designed to convey a complaint against the third party. In the responses that we look at here, the therapist focuses on this aspect, i.e. conduct of the third party, rather than on the patient's experience as such (Voutilainen et al. 2010). Further, the therapist shares the (more or less embedded) negative stance taken by the patient, and makes more explicit the transgression by the third party. In other words, the therapist allies with the patient against the third party. How overtly the therapist takes this kind of position varies in the responses. On the other hand, these responses also convey inherently as part of a wider therapeutic activity, i.e. working with the patient's experience and thoughts - an orientation to the patient's inner experience. Our focus here is however on the displays of the therapist's own negative stance towards the third party and their function in these therapist's actions. To avoid confusion with sequences where complaining is the primary activity (Drew and Walker, 2009), we refer to this aspect of the patient's and therapist's descriptions as criticism or critique of a third party.

In what follows we will describe two practices of the therapist: one in which the therapist confirms the critique that the patient has implied or expressed in her previous remarks, and one in which the therapist returns to the critique from which the patient had previously focused away. We suggest that the therapist uses these practices as a means of validating the patient's emotion that is conveyed in the critique on the third party. In the latter part of the paper, we will show how the collaboratively expressed critique becomes framed by, and serves as argumentative grounds for, a manifest institutional action of cognitive therapy; that is, challenging dysfunctional beliefs (Beck 1976).

The practices that we describe below are recurrent in the data: we have collected altogether 40 cases. The data extracts that we use in the two following sections are however from a discussion in one therapy session. This is to simplify the descriptions of the context and to avoid disclosing too much about the patient's circumstances. 


\section{Confirming the patient's critique}

In the cases that we will look at now, the patient has started increasingly to criticise the 'third party' (here the patient's partner) in her descriptions of her problematic experiences. In what we call confirming the patient's critique, the therapist continues the critique that the patient has implied or expressed in her previous turn. In designing her contributions, the therapist not only understands and recognises (Voutilainen et al. 2010) but shares the patient's critical stance (Drew 1998, Drew and Walker 2009, Ruusuvuori and Lindfors 2009, Jeffersson 1988, Ruusuvuori 2007).

Extract 1 below shows a sequence where the therapist twice confirms the patient's critique. Earlier in the session, the patient had told how her partner had recently been away from home at night for several hours without telling where he was going. The therapist and the patient have been talking about how the patient feels about her partner's conduct. Within this talk there have been several instances where the participants have agreed how badly the partner has treated the patient. Before this extract the patient has however expressed partial understanding of the partner's conduct. Extract 1 begins from a point in the patient's long account where she is shifting from that understanding back to criticising her partner for not telling her where he was going. The patient has pointed out that she also sometimes gets spontaneous invitations to parties and goes on to compare her partner's conduct with her own.

\section{Extract 1}

2

3

$4 \mathrm{~T}:$

$5 \quad \mathrm{P}$ :

$6 \quad \mathrm{~T}:$

P:
$1 \quad$ P: $\quad$.hhhhhh mmm $\uparrow$ but still $\uparrow$ I have $\uparrow$ always said .hhhhhhhh mmm $\uparrow$ mut $\uparrow$ et $\uparrow$ aina oon sanonu kuitenki where I'm going so that first of all you $\uparrow$ don't minne menen $\uparrow$ ettei $\uparrow$ tarvii ensinnäkään $\uparrow$ need to get wor[ried

$$
\text { huoles[tua }
$$

[Yeah (.)[yeah.

[Nii (.) [nii.

[if the other stays late. $=$

[et jos ei kuulu kotiin. $=$

$\mathrm{T}$ : $\quad=$ Yeah (.) so you know where the other is and what's $=$ Nii (.) et tietää mis on ja seki että o: olis voinu more you could have imagined that many people would kuvitella et moni olis have said like why don't you come along too (.) vaik sanonu tuu säki.(.)

P: $\quad \uparrow Y$ ea-h (.) yeah. $\uparrow$ Niii-i (.) nii.

(.)

T: $\quad$ Mmm. $=$

P: $\quad=$ Yeah.

$=$ Nii.

$(0.5)$

$\mathrm{T}$ : If one leaves for a party [or. Jos lähtee bileisiin [tai.

[Yeah (.) so $\uparrow$ indeed (.) indeed

[Nii (.) et $\uparrow$ kyllä (.) kyllä 
$18 \quad$ P:

$19 \mathrm{~T}$ :

$\mathrm{P}:$

I like (.) .hfffff (.) was li- li- little \#erm\# mun niinku (.) .hfffff (.) hi- hi- hieman \#nnn\# .hhhhhh to put it mildly it felt bad (0.3) .hhhhhh lievästi sanottuna pahalta tuntu (0.3) [and it still feels the thing that. [ja tuntuu se että. [Pt (.) I think that is quite justified and [Ts (.) mun mielestä ihan oikeutetusti ja mun I think that that is $\uparrow_{\text {mistrea }}{ }^{\circ}$ tment $^{\circ}$. mielest toi on $\uparrow$ huonoo ${ }^{\circ}$ koh|teluu ${ }^{\circ}$.

I can't $\uparrow$ get angry hhhhhhhhhh. [Yeah (2.0) $\uparrow$ but $\uparrow$ I $\uparrow$ mean

[Nii (2.0) $\uparrow$ mut $\uparrow$ että $\uparrow \mathrm{ku}$ mä en osaa $\uparrow$ olla vihanen hhhhhhhhhh.

(1.2)

In lines 1-5 the patient states that she herself has always told her partner where she goes so that her partner does not need to get worried. As she has just said that this is something that her partner has not done, she builds a comparison indicating that her own way of doing things is in contrast to her partner's. She also states that she always says where she goes and gives a rationale for this (so that the other does not have to worry) and this way implies that hers is the proper way to act in an equivalent situation. Thus, she can be heard to imply that her partner has committed a transgression (Drew 1998, Halonen 2005). In line 6 the therapist validates the norm that the patient has implied by giving more grounds for why it should be obeyed and then in lines 6-8 and 14 adds to it: 'and what's more one could have imagined that many people would have said like why don't you also come along'. The therapist thus adds an extra element to the critique: the partner could have told about his whereabouts but it could also be commonly expected that he would have asked his partner to come along. Thus, she suggests that the partner's conduct had much to be desired (Drew and Walker 2009, Ruusuvuori 2007).

The patient responds in lines $15-18$ by stating that 'to put it mildly' what the partner did 'felt bad'. The patient's reference pronoun 'it' (lines 17 and 18 in the translation) brings the discussion back to the actual event that she started with, that the partner did not tell her about his whereabouts. With 'so indeed' (line 15) the patient indicates that the upshot is based on what has been collaboratively formulated: that the conduct of her partner makes one feel bad. The patient's contribution makes possible both further escalation of the critique (Drew and Walker 2009) and, on the other hand, a shift from focusing on her partner's conduct to focusing on her own experience. In her response in lines 19-20, the therapist retains the critical perspective towards the partner by stating that she thinks that the patient's bad feeling is quite justified and that what the partner did was mistreatment (the word 'toi' ('that') in line 20 refers to the concrete event that the patient had just re-evoked in line 17). Now the therapist manifestly marks her statement as her own opinion ('I think' in lines 19 and 20) and thus explicitly displays alliance with the patient against the third party. She also states that she sees the patient's emotional reaction as 'justified' (line 19). This justification is, we suggest, what the therapist indicates also in the less manifest cases: through confirming the patient's critique the therapist demonstrates that she sees the emotion conveyed in the critique as valid and reasonable (see Linehan 1997). In lines 21-2 the patient however turns from criticising her partner to another kind of activity: to reflecting her inability to express anger (Drew and Walker 2009 about going too far in escalating complaints). 
Extract 2 is from a couple of minutes later in the session. The patient has said how she would feel like revenge but how she also feels that her partner would not mind if she did the same thing to him. The therapist has pointed out that this does not mean that the patient would need to start acting like her partner. The extract begins from the patient's response to this.

\section{Extract 2}

$1 \quad$ P: $\quad=$ So I indeed tried to say to him that well $\underline{\mathrm{I}}$

$=$ Et ku mä yritinki sille että no minusta

felt bad I felt that it was wrong so that se tuntu pahalta MINUSTA se oli väärin tehty et DOESN'T [that mean anything EIKS [se merkitse mitään

$\begin{array}{ll} & \text { T: } \\ & \text { [Neah } \\ & \text { [Nii. }\end{array}$

6 P: $\quad[. h h h$ so is it the only right opinion that .hh

$7 \quad$ P: $\quad$ you think that $=$

8 T: $\quad=$ Yeah land then as if your feelings were wrong $=$

$9 \quad \mathrm{P}$

10 P: =Yea:h (.) yeah. $=$

$11 \quad$ T: Nii: $($.$) nii. =$

11 T: $=$ Yeah. $=$

$12 \quad$ P: $\quad$ = Yeah that's just what I try to say that .hhhh = Nii et sitä mä yritän just sanooakki että no .hhhh

13 ALWAYS say to Ville that well (.) what I feel is ÂINA Villelle se että no (.) se mitä mä tunnen on

$14 \quad$ like right I mean in that way niinku oikee siis ei sillä lailla

$\# \mathrm{~m}[\mathrm{~mm} \#$ (.) not glob [ally right but $\# \mathrm{~m}[\mathrm{~mm} \#$ (.) yleismaallises mai[sesti oikeen vaan

16 T: $[\mathrm{Mmmm}$. $[\mathrm{Mmmm}$.

17 P: like in me \#erm\# right to [me niinku minussa \#a-o\# mi [nulle oikein. =

18 T: $\quad$ T:

19 T: $\quad=$ Mm mm pt and the question is if he wants to $=\mathrm{Mm} \mathrm{mm}$ ts ja kysymys et haluuks hän ottaa sen

$20 \quad$.hh[hhh

21 P: $\quad$ [.hhhhhhhh. Nii. $=$

22 T: $\quad=$ take that into acjcount.

23 P: $\quad$ huomio $\quad \begin{array}{ll}\text { [on. } \\ \text { [Yeah. }\end{array}$

$24 \quad(0.3)$

$25 \quad \mathrm{~T}: \quad$ Like say like just $(0.4)$ like to

Niinku sanotaanko vaikka niinku ihan (0.4) vaikka 
In lines 1-3 and 6-7 the patient reports what she has said to her partner. This report conveys a critique of the partner for not taking seriously the patient's emotional reaction (through questioning her partner's conduct in lines 3: 'DOESN'T that mean anything' and 6: 'is it the only right opinion that you think that'). In response to this in line 8 the therapist first affiliates with the patient's stance according to which the partner's conduct has been transgressive or at least questionable. This is done through the affiliating turn initial response particle 'nii' (in the Finnish data) (see Sorjonen 2001). With and-preface the therapist also designs her turn to talk as a continuation of the patient's turn and this way indicates sharing the patient's perspective on the matter. Thereafter, she adds a description of the partner's dismissive attitude ('Yeah and then as if your feelings were wrong), indicating that the issue that the patient has reported, the partner's way of treating his own way of doing things as the only proper one, simultaneously means neglecting the patient's own feelings. This way, while confirming the criticism of the third party, the therapist also maintains the focus on the patient's emotional experience of being neglected (by referring to 'your feelings').

In lines 10, 12-15 and 17 the patient agrees with the therapist's description, and continues by telling how she always tries to make her partner understand that her emotions are valid. This telling unites perspectives in the same way as the therapist's previous turn: on the one hand the patient talks about the third party (the partner does not understand the validity of the patient's emotions) and on the other hand she talks about herself (her emotions are valid).

In her further response in lines 19-20, 22 and 25 the therapist again takes the focus on the third party by stating that the question is whether the partner wants to take that (the validity of the patient's emotions) into account. In line 25-6 the therapist expands this by the qualification 'Like say like just (0.4) like to reasonable extent if not more', which indicates that, from an external perspective (marked through the preliminary 'say' in line 25), the partner's conduct was far from reasonable (see Drew 1998). The patient continues this line of thought by describing how she is not demanding much from her partner, and thus indicates that it would indeed be reasonable for the partner to take the patient's emotions into account (lines 27-8).

In the two extracts above, the therapist confirmed the critique that was embedded in the patient's previous contributions. She kept the focus on the conduct of the third party, and shared the patient's stance. The instances of interaction described above have similarities with what Drew and Walker (2009) have reported on complaints in everyday conversation: in sequences of complaining, both/all co-participants formulate versions of the complaint and add to the other's versions - so that the complaint escalates turn by turn. However, unlike in the sequences described by Drew and Walker, the environment in which this happens in our data is not only that of an emergent complaint but the 'complaint' (or criticism as we call it) is one aspect in a wider, institutional activity: discussing the patient's problematic experience and examining her thoughts related to that experience. The critique on the third party gets attended to and collaboratively formulated at some points of this discussion, and either of the participants can smoothly move from focusing on the conduct of the third party to other 
perspectives: to describing the patient's experience or examining her reasoning about the situation.

\section{Returning to the critique}

In the case of returning to the critique, the patient has moved away from criticism of the third party to taking a different perspective on the situation, and the therapist takes the focus back to the conduct of the third party. At the beginning of the next extract the patient moves to talk about her jealousy of and doubts about her partner.

\section{Extract 3}

\begin{tabular}{|c|c|c|}
\hline 1 & P: & 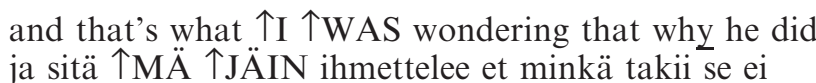 \\
\hline 2 & & $\begin{array}{l}\text { not say (.) what's .hhhh and then my mind is }(0.6) \\
\text { sanonu (.) mikäs .hhhhh ja sit ku mun pää on }(0.6)\end{array}$ \\
\hline 3 & & $\begin{array}{l}\text { so }<\text { s- sick }>\text { from the jealo [usy so } \\
\text { niin }<\text { s-sairas }>\text { siitä mustasuk[kasuudesta niin }\end{array}$ \\
\hline 4 & $\mathrm{~T}:$ & $\begin{array}{l}\text { [Krh kryhm. } \\
\end{array}$ \\
\hline 5 & P: & $\begin{array}{l}(0.4) \text { so it did make me }(.) \text { wondering }(.) \\
(0.4) \text { kylhän se niinku jäi niin (.) vaivaamaan }(.)\end{array}$ \\
\hline 6 & & $\begin{array}{l}\text { Tyou know I dont' know where he was .hhh I did } \\
\text { 个enhän mä tiedä et missä se oli .hhh en mä sit }\end{array}$ \\
\hline 7 & & $\begin{array}{l}\text { not even want to ask that anymore so (.) I } \\
\text { halunnu edes kysyä enää että (.) mä aattelin }\end{array}$ \\
\hline 8 & & $\begin{array}{l}\text { thought that I let [that pass then. } \\
\text { että no olkoon [sit että. }\end{array}$ \\
\hline 9 & $\mathrm{~T}:$ & $\begin{array}{l}\text { [.hfff Well even if one were not an } \\
{[. h f f \text { No vaikkei nyt ois }}\end{array}$ \\
\hline 10 & & $\begin{array}{l}\text { Tespecially jealous person wasn't it what } \\
\text { 个erityisemmin mustasukkanen ihminen nii eiks se }\end{array}$ \\
\hline 11 & & $\begin{array}{l}\text { like your mother said too .hhhh that I suppose } \\
\text { niinku sun äitiki sanonu että .hhhhh et kai sitä nyt }\end{array}$ \\
\hline 12 & & $\begin{array}{l}\text { usually cou:p couples tell } \\
\text { yleensä mm pari: pariskun|nat kertoo }\end{array}$ \\
\hline 13 & P: & $\begin{array}{l}{[\uparrow \text { Yeah }(.) \downarrow \text { yeah. }} \\
{[\uparrow \text { Nii }(.) \downarrow \text { nii. }}\end{array}$ \\
\hline 14 & $\mathrm{~T}:$ & $\begin{array}{l}\text { each other where they go. }= \\
\text { toisilleen minne ne menee. }=\end{array}$ \\
\hline 15 & P: & $\begin{array}{l}=\text { Yea-h. } \\
=\text { Nii-i. }\end{array}$ \\
\hline 16 & & $(0.4)$ \\
\hline 17 & P: & $£$ Nhii-i (.) .hh[hhhh.£ \\
\hline 18 & $\mathrm{~T}:$ & $\begin{array}{l}\text { [So it is [quite. } \\
\text { [Että se on [aika. }\end{array}$ \\
\hline 19 & P: & $\begin{array}{l}\text { [And and Ville's opinion was that } \\
\text { [Ja ja Ville oli sitä mieltä et }\end{array}$ \\
\hline
\end{tabular}

In lines 1-8 the patient describes her worry about why her partner did not tell her where he was going, and presents 'her mind [as] being sick from jealousy' at least as a partial reason for her worry. In her response in lines 9-12, 14 and 18 the therapist does not focus on the patient's worry or jealousy but shifts away from it ('Well even if 
one were not an 个especially jealous person' in lines 9-19) back to the partner's conduct, by stating that usually people in relationships do tell each other where they go. By referring to general standards and to what also the patient's mother has said (line 11), the therapist again displays that she evaluates the situation from an external perspective and makes her own statement about it. Thus, the therapist points out that the problem is not the patient being too jealous to bear her partner's conduct but the partner's conduct being just inapt in terms of the norms of the social world. She conveys that the patient being upset about her partner's conduct is valid, reasonable and normal; and thus counters the 'letting go' that the patient described in lines 7-8. The patient continues in the perspective offered by the therapist from line 19 on by telling how the partner did not take the patient's berating seriously (not shown in this extract).

Extract 4 shows another case of returning to the critique of the third party. The extract is earlier from the session than the ones shown above. In this case, rather than merely criticising the third party, the therapist refers to the critique as a part of challenging the patient's reasoning.

\section{Extract 4}

$1 \quad$ P: $\quad(0.4)$ no I do know that it's not that way it's not

(0.4) ei kyl mä tiedän että ei niin et ei se

(0.4) that I would have to .hh humble myself and

(0.4) niin ole että mun pitäis .hh nöyrtyä ja

take it all and .hh (.) kindly and $\uparrow$ and (0.5) but

hyväksyä kaikki ja .hh (.) kiltisti ja $\uparrow$ ja (0.5) mut

(.)

$9 \quad$ P: $\quad$.hfff $(0.4)$ well it's not $\downarrow$ recurrently mistreating

In lines $1-6$ the patient tells of her reasoning about how she should react to her partner's conduct. In line 3 she moves from defending her position (conveying a presupposition that the partner's conduct is not acceptable) - to expressing worry about losing her partner (conveying that she believes she should accept the partner's conduct so that she would not lose the partner). As response to this, in line 7 the therapist presents a counter-argument: 'But if he recurrently mistreats you'. As in the previous extract, the therapist thus bypasses the patient's expressed experience (worry) and takes the focus back to the transgression by the partner. The overtly contrasting (challenging) relation to the patient's preceding contribution brings to this one also characteristics of another action: challenging the patient's thinking. The therapist questions the rationality of the patient's fear of losing a partner who mistreats her. In this case, the therapist goes noticeably further in pointing out the transgressions of the 
partner than the patient has done in the session, as she indicates that the partner recurrently mistreats the patient. The patient rejects the element that was added by the therapist (in line 9) (Drew and Walker 2009).

Above, we have described two practices where the therapist either confirmed or re-revoked the patient's critical stance on the conduct of a third party. The therapist's actions resemble what participants in everyday interaction do when affiliating with each others' complaints: they not only recognise but share the critical stance expressed by other participants (Drew 1998, Drew and Walker 2009). We suggest that in their context as part of therapeutic work with the patient's problematic experience, these practices work for validating the patient's emotional reaction to her partner's actions (and non-actions). They convey that the patient's emotion is justified, reasonable and normal in terms of the facts in the patient's circumstances (see Linehan 1997).

The therapist's actions invite further agreement from the patient (see Extracts 1 [after the first therapist's response], 2 and 3). As we have seen, however, the patient can also challenge the critique as it was expressed by the therapist (as was the case in Extract 4), or shift the perspective away from it (as after the therapist's second response in Extract 1). We suppose that each of these moves by the patient enable further work on the patient's relation to the problematic experience under discussion. However, besides its local functions, the therapist's work described above also serves for another institutional task of cognitive therapy: challenging dysfunctional beliefs and suggesting alternative reasoning (see Beck 1976). In what follows we will show how the sequences of criticising a third party become connected to the therapist's utterances where such challenges and suggestions are made.

\section{Cognitive reasoning as a frame}

In the course of interaction where the therapist uses the practices described above, she has a certain interactional project (see Schegloff 2007: 244-9): she challenges the patient's belief in being at fault and not having the right to get angry at others. The therapist's practices of keeping the focus on the conduct of the third party and validating the patient's stance serve this wider purpose. The next extract shows how the mutually expressed critique of the third party serves as grounds for the therapist's argument about the patient's dysfunctional belief. This extract is from a different session from the extracts above, but as in those, the talk is about the patient's partner.

\section{Extract 5}

$1 \quad$ P: $\quad$ does he take it for granted that (1.7) onko se niinku sille ihan itestääselvää että (1.7) I am (0.6) kind and (1.0) humble and that että mä oon (0.6) kiltti ja (1.0) nöyrä että @.hhhhhhh@(0.8) he does not even ᄂthink@anymore@

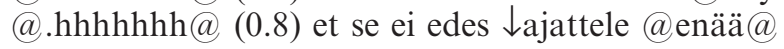
(.)\#like\# (.) how he behaves and (2.6) or (.)\#niinku\# (.) miten se käyttäytyy ja (2.6) vai is he then so selfish that (0.6) and somehow onko se sitte niin itsekäs että (0.6) ja jotenki proud hhh that like (1.3) he has to be able to ylpee hhhh että tota (1.3) sen on saatava tehä 


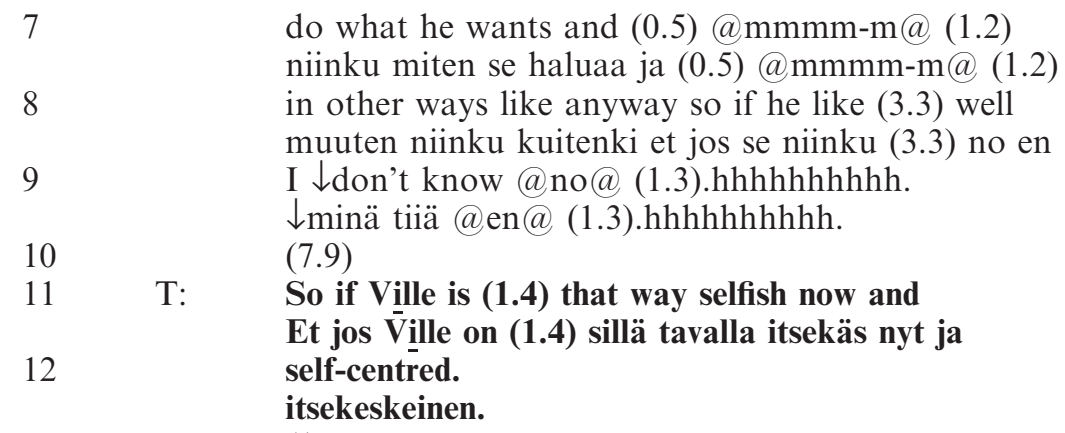
14 P: Yeah.
Nii.
$15 \quad(2.6)$
16 P:@@.hhhhhhhh@.
$17 \quad$ (1.2)
18 P: Krhm krhhhhhhhhhhh.

19 T: $\quad$ Pt right .hff so maybe he would for example behave

Ts nii .hff et jospa se esimerkiks käyttäytys

like that (.) with who (0.3) ever like (1.7).hh noin (.) olis siinä kuka (0.3) hyvänsä niinku (1.7) so if there (-) somebody else he would be the same. .hh et siinä (-) joku muu jos se olis samanlainen.

(.)

P: $\quad$ Well n: yeah I don't know (.) ca:n be.

No e:- nii en tiiä (.) vo:i olla.

(13.9)

P:@@.HHHHНHнHH@.

(2.2)

$\mathrm{T}$ : $\quad$.hff $(0.3)$ But then it would of course .hhhhh tell .hff (0.3) Mut sillonhan se tietenki .hhhhhh kertois more about what Ville is like than about that $y-($. enemmän siit millanen Ville on kun siitä et s- (.) that there's something wrong with you. et sus ois jotain vikaa.

(.)

P: $\quad$ Ts yea-h hhhhhhh.

Ts nii-i hhhhhhh.

P:@@.hhhhhhh@.

(2.4)

P: hhhhhhhh.

(31.3)

P: $\quad$ Ts (0.4) phhhhhhh. (5.4)

P: $\quad \uparrow I$ don't like even dare to $\downarrow_{\text {say }}$ anything

$\uparrow$ En mä niinku uskalla sille sitte mistään $\downarrow_{\text {sanookaan }}$ to him any more .hhh like (3.9) so that he would not enää yhtään mitään .hhh niinku (3.9) ettei se get hurt or angry(0.5)@.hhhhhhhh@(1.6) mhhhhh. loukkaannu tai suutu(0.5)@.hhhhhhhh@(1.6) mhhhhh. 
In lines 1-9 the patient ponders why her partner acts in the way he does. One line of reasoning that the patient offers is that her partner is so selfish that he just needs to do what he wants (lines 5-7). The patient presents her reasoning as a series of questions whereby she tests various negative qualifications of her partner as possible explanations for his undesirable conduct: is he just so selfish and proud? She also makes a negative observation of him not even thinking about his behaviour any more. This drawing upon the context can be seen to refer to not having to think about how he behaves, as the patient is so kind and humble. These tentative negative qualifications and observations amount to implying a critical stance towards her partner.

In her response to this in lines 11-12 the therapist picks on the patients' consideration about the selfishness of the partner and begins, through if-preface, to formulate a question or conclusion on that selfishness. In lines 19-20 the therapist expands the if-sentence by explaining what the partner's selfishness involves: that the partner would behave in the same way in relation to anyone. This expansion confirms the patient's stance as the therapist adds to the categorisation of the partner as selfish that was introduced by the patient. Then in lines 27-29 the therapist goes on to the conclusion of her construction: she suggests that the partner's selfishness means that the patient should not blame herself.

In this way, the therapist challenges the patient's dysfunctional belief in the form of a logical conclusion from the critique that was expressed by the patient. In this case, however, the patient does not take up the therapist's suggestion but after a minimal agreement (line 31) the patient moves on to express a fear of expressing her anger to her partner (from line 39 on) (see Extract 1). The patient's way of receiving the therapist's suggestion seems to imply that the patient takes the reason that the therapist suggests as given (not needing elaboration after agreement). Nevertheless, the problematic experience remains (the patient feels that she is not able to act according to that reason).

In this case, the therapist shares the patient's critique (the assessment about the partner as selfish) within an argumentative turn construction (conclusion). In other cases, the critique and the therapist's arguments are more separated and they become connected retrospectively ${ }^{1}$. This is the case in the session which included Extracts 1-4. The next extract shows how the therapist in this session goes on to question the patient's beliefs. Before the extract the therapist and the patient have talked about whether the patient's experiences could be different with a different partner. The patient has finished this line of talk by stating that she does not want to separate from her partner. The extract begins from the therapist's response to that.

\section{Extract 6}

\begin{tabular}{|c|c|c|}
\hline 1 & $\mathrm{~T}:$ & $\begin{array}{l}<\text { Yeah }>\text { I understand that you don't want }(1.8) \\
<\text { Niin }>\text { mä [ymmärrän et sä et haluu }(1.8)\end{array}$ \\
\hline 2 & &.$h f f f($.$) .hff$ \\
\hline 3 & P: & $\begin{array}{l}\text { [Mmmm it doesn't. } \\
{[\mathrm{Mmmm} \text { ei se. }}\end{array}$ \\
\hline 4 & $\mathrm{~T}:$ & $\begin{array}{l}\text { but then on the other hand it is a thought too that } \\
\text { mut et toisaalta sekin on ajatus että }\end{array}$ \\
\hline 5 & & $\begin{array}{l}\text { hhh that you e:rm hhh }(0.7) \text { that sounds like really } \\
\text {.hhhh että sää tuota: hhhh }(0.7) \text { tuo kuulostaa tosi }\end{array}$ \\
\hline 6 & & $\begin{array}{l}\text { Tbad [that you } \\
\uparrow \text { pahalta [et sä }\end{array}$ \\
\hline 7 & P: & [Mmmm hhhhhhh. \\
\hline 8 & $\mathrm{~T}:$ & $\begin{array}{l}\text { thought that you will kill yourself and .hhhhhhhh } \\
\text { mietit et sä tapat itses ja .hhhhhhh }\end{array}$ \\
\hline
\end{tabular}


as actually the way it goes is that (.) Ville sua $\uparrow$ huonosti (.) ja sä päätät tappaa itsesi

.hhhh. $=$

12 P: $\quad=£$ Mhhh£.

P: Nii:.

(.)

$\mathrm{T}$ : $\quad$ Because Ville is behaving badly (.) because Ville Sen takia et Ville käyttäytyy huonosti (.) Ville is an idiot on ääliö.

P: $\quad$ Nii: [£hhhh (0.3) .hhhh no ehh .hh no ei: (.)

but $\mathrm{s}(\mathrm{h})$ omehow I did not think it that mut $\mathrm{j}(\mathrm{h})$ otenki en mä nyt sitä nyt ajatellu ihan noin simple (0.4) .hhh way so (0.7) soi t was because of ykss£ (0.4) .hhh selitteisesti että (0.7) et Villen Ville that I (1.0) was going to (.) or like would I takia mä nyt (1.0) meinaisin (.) tai niinku olis en was not going to but (1.0) thought (.) about it. nyt meinannu siis (1.0) oli (.) mielessä. .hff Mut et noinhan se niinku $\uparrow$ tavallaan on. $=$

P: $\quad=$ Yea-h. $=$

$=$ Nii-i. $=$

$\mathrm{T}: \quad=$ The situation is that Ville behaves badly .hhhhh

$=$ Toi tilanne et Ville käyttäytyy huonōsti .hhhhh the end result is that you want to die. lopputulos on se että haluut kuolla. Nii todennäkösesti se ei si- niitä ajatuksia ois not have come if like .hhhh (0.4) the situation was tullu jos niinku .hhhhh (0.4) tilanne ois hoidettu managed in some (.) different way $(0.5)$ by Ville. vähän (.) erilailla (0.5) Villen osalta.

(.)

T: $\quad$ Yeah (1.1) but I mean do you have to get those

Nii (1.1) mut et tartteeks sul tulla niitä 
thoughts then when the other mistreats you ajatuksia sillon ku toinen kohtelee sua huonosti

42 P: $\quad[. h f f f f f f . h h h h h h h h h h$ (.) pt well no (1.0) mhhh. [.hffffff .hhhhhhhhhh (.) ts no ei (1.0) mhhh.

44 T: $\quad$ So in a way (.) the other is bad (.) then you begin Et tavallaan (.) toinen on paha (.) niin sä rupeet to think that $\uparrow \mathrm{I}$ am so [bad that it's better that aattelee et $\uparrow$ mä oon niin [paha et mun on viisaampi hhhh£.

In lines 1-2, 4-6 and 8-11 the therapist makes a shift from the patient's unwillingness to separate from her partner to the patient's dysfunctional reactions: to stating that it sounds bad that the patient starts to think about killing herself when her partner has mistreated her. The presupposition that this statement contains - the partner has mistreated the patient - has been collaboratively agreed on, by this very same phrasing, earlier in the session (see Extracts 1 and 4). So, the therapist uses here the mutually agreed critique as a resource and grounds for challenging the patient's dysfunctional reaction (thinking about killing herself) and the dysfunctional belief behind that (being at fault and having no right to get angry).

In this case, unlike in the previous extract, the patient takes up the therapist's point (from line 22 on) and the talk continues with elaboration of it. In lines 35-36, after the therapist's persuasion (lines 28-31) the patient accepts the relation between her partner's conduct and her suicidal thoughts. The patient however does this in the frame of stating the bad consequences of the partner's conduct, and does not take up self-reflection on the working of her mind, i.e. her tendency to react with suicidal thoughts instead of expressing anger. In her response in lines 39-40, the therapist now takes the mistreatment by the patient's partner as given, and focuses on what that conduct awakes in the patient. Thus, at this point the therapist, as it were, closes the circle that has been made in this session: she takes the focus back to the patient from focusing on the conduct of the third party.

In summary, in our data the therapist's responses that ally with the patient against a third party serve a therapeutic aim of challenging the patient's dysfunctional beliefs. Through the practices of confirming the critique and returning to the critique, the therapist keeps the focus on the conduct of the third party and validates the critique (and emotion conveyed in it) that the patient has offered. This validated critique then serves as grounds for arguments that challenge the patient's belief in being at fault and having no right to get angry.

\section{Conclusions}

In psychotherapy theory, the therapist's empathetic attitude is often seen as something that facilitates the collaborative relation between the patient and the therapist (e.g. Greenson 
1967, Beck et al. 1979). The collaborative relation then makes it possible for the participants to engage in proper psychotherapeutic action, be it interpretation of transference or challenging dysfunctional beliefs. Empathy, in other words, maintains a kind of 'interactional and emotional infrastructure' of psychotherapy. Our analysis confirms this kind of understanding, but it also points out that there is more in these particular empathetic (validating) responses in which the therapist allies with the patient against a third party. By validating the patient's criticism of the third party, the therapist in our data not only maintained a general sense of alliance between herself and the patient. Validation of the patient's emotion, in this case, was a vehicle for the specific action of challenging the patient's beliefs.

What we have reported in this paper is a case study of the interactions of a particular therapist-patient dyad. While it is reasonable to assume that therapists work differently with patients whose problems are different, what we have shown in detail is one way in which validation of a patient's emotion occurs in practice, and how it is linked to challenging the patient's beliefs (see Peräkylä and Vehviläinen 2003).

In more general terms, our analysis explicated a pocket of non-neutrality in professional action. We have pointed to similarities in the therapist's responses described in this paper with affiliation with complaints towards a third party in everyday talk: the therapist shared the patient's implied or explicit critique, and indicated that the third party had transgressed moral standards (Drew 1998, Drew and Walker 2009). Thus, one context, which the therapy interaction can invoke, is that of the 'everyday social world' with its moral codes (such as 'usually partners tell each other where they go'). Moreover, the connection that the therapist builds between the critique of the third party and questioning the dysfunctional beliefs, suggests that the functional perception of reality that cognitive therapy pursues, can be, among other things, practising the kind of everyday morals to which people orient in mundane complaining (Drew 1998). The therapist used resources of 'mundane nonneutrality' to draw a line between functional and dysfunctional, i.e. between healthy reactions to mistreatment and the patient's beliefs.

In theoretical terms, our case analysis on one psychotherapy process lends support to those authors who suggest that (successful) professional action does not always involve such affective neutrality that Parsons (1951) and Freud (1915), among others, described in their classical texts. In his insightful passage showing parallels between psychotherapy and medicine, Parsons (1951: 461) pointed out that in order to be helpful and not merely to repeat the vicious circles of the patient's other human relations, the psychotherapy relation needs an 'Archimedean place to stand', placement 'outside the reciprocities of ordinary social intercourse'. This placement, according to Parsons, is provided by the institutionally backed objectivity and affective neutrality of the therapist. We do not call in question the general validity of the Parsonian view, but we have shown a specific interactional context where the therapist successfully got involved in, and made use of, the reciprocities of ordinary social relations. In this case, the very resources of ordinary social intercourse, i.e. practices of expressing moral and affective stance in everyday conversation, were used to accomplish institutional tasks of psychotherapy. In other words, in this case, the non-neutrality of the professional was not a lapse from the actual institutional business. Rather, it was shown to be a tool for the professional to achieve her very institutional task.

Address for correspondence: Liisa Voutilainen, Department of Social Research, University of Helsinki, P.O.Box 4, Vuorikatu 4, University of Helsinki, 00014, Finland e-mail: liisa.voutilainen@helsinki.fi 


\section{Acknowledgements}

We would like to thank Hanna Falk, Taru Ijäs and Mikko Kahri for comments on earlier versions of the manuscript, along with other members of data sessions in which the data were discussed. Thank you also to Katri Takala and other transcribers of the data. The research was made possible by Academy of Finland project 110845 (Emotion, interaction and institutions).

\section{Note}

1 In some cases the therapist confirms/returns to the critique also after questioning the beliefs, and so reinforces the grounds for the conclusion.

\section{References}

Antaki, C., Barnes, R. and Leudar, I. (2005) Diagnostic formulations in psychotherapy, Discourse Studies, 7, 6, 627-47.

Arminen, I. (2005) Institutional Interaction. Aldershot: Ashgate.

Beck, A.T. (1976) Cognitive Therapy and the Emotional Disorders. New York: International Universities Press.

Beck, A.T., Rush, A.J., Shaw, B.F. and Emery, G. (1979) Cognitive Therapy of Depression. New York: The Guilford Press.

Bercelli, F., Rossano, F. and Viaro, M. (2008) Clients' responses to therapists' re-interpretations. In Peräkylä, A., Antaki, C., Vehviläinen, S. and Leudar, I. (eds) Conversation Analysis and Psychotherapy. Cambridge: Cambridge University Press.

Bergmann, J. (1992) Veiled morality: notes on discretion in psychiatry. In Drew, P. and Heritage, J. (eds) Talk at Work: Interaction in Institutional Settings. Cambridge: Cambridge University Press.

Bergmann, J. (2008) Noticings - a genuine psychotherapeutic device. Presentation at the conference: Conversation Analysis and Psychtherapy. Göttingen, 9 - 11 October, 2008.

Bershady, H.J. (2005) Affect in social life. In Fox, R.C, Lidz, V.M. and Bershady, H.J. (eds) After Parsons: a Theory of Social Action for the Twenty-First Century. New York: Russell Sage Foundation.

Clayman, S.E. (1992) Footing in the achievement of neutrality: the case of news interview discourse. In Drew, P. and Heritage, J. (eds) Talk at Work: Interaction in InstitutionalSettings. Cambridge: Cambridge University Press.

Clayman, S. and Heritage, J. (2002) The News Interview: Journalists and Public Figures on the Air. Cambridge: Cambridge University Press.

Drew, P. (1992) Contested evidence in a courtroom cross examination: the case of a trial for rape. In Drew, P. and Heritage, J. (eds) Talk at Work: Social Interaction in Institutional Settings. Cambridge: Cambridge University Press.

Drew, P. (1998) Complaints about transgressions and misconduct, Research on Language and Social Interaction, 31, 3-4, pp. 295-325.

Drew, P. and Walker, T. (2009) Going too far: Complaining, escalating and disaffiliation, Journal of Pragmatics, 41, 12, 2400-14.

Drew, P. and Heritage, J. (1992) Analyzing talk at work: an introduction. In Drew, P. and Heritage, J. (eds) Talk at Work: Interaction in Institutional Settings. Cambridge: Cambridge University Press.

Fox, R.C. (1979) Essays in Medical Sociology: Journeys into the Field. New York: John Wiley. 
Freud, S. (1915) Observations on Transference-love. Standard Edition, Vol. 12. London: Hoghart Press.

Garcia, A. (1991) Dispute resolution without disputing. How the interactional organisation of mediation hearings minimises argumentative talk, American Sociological Review, 56, 6, 818-35.

Greatbatch, D. (1992) On the management of disagreement between news interviewees. In Drew, P. and Heritage, J. (eds) Talk at Work: Interaction in Institutional Settings. Cambridge: Cambridge University Press.

Greenberg, J.R. (1986) Theoretical models and the analyst's neutrality, Contemporary Psychoanalysis, 22, 1, 89-106.

Greenson, R.R. (1967) The Technique and Practice of Psychoanalysis. Madison: International Universities Press.

Guidano, V. (1991) The Self in Process. New York: Guilford Press.

Gunthner, S. (1997) Complaint stories: constructing emotional reciprocity among women. In Kotthoff, H. and Wodak, R. (eds) Communicating Gender in context. Amsterdam: John Benjamins.

Haakana, M. (2007) Reported thought in complaint stories. In Holt, E. and Clift, R. (eds) Reporting Talk. Reported Speech in Interaction. Cambridge: Cambridge University Press.

Halonen, M. (2005) Mä en sit siihe sanonu mitää - Raportit sanomatta jättämisestä ja evidentiaalinen partikkeli sit(te(n)) keskustelun kertomuksissa, Virittäjä [Journal of Finnish Linguistic Studies], 109, 2, 271-98.

Halonen, M. (2006) Life stories as evidence for the diagnosis of addiction in group therapy, Discourse and Society, 17, 3, 283-98.

Heisterkamp, B.L. (2006) Conversational displays of mediator neutrality in a court-based program, Journal of Pragmatics, 38, 12, 2051-64.

Jefferson, G. (1988) On the sequential organization of troubles-talk in ordinary conversation, Social Problems, 35, 4, 418-41.

Kimerling, R.E., Zeiss, A.M. and Zeiss Robert, A. (2000) Therapist emotional responses to patients: building a learning-based language, Cognitive and Behavioural Practice, 7, 3, 312-21.

Kohut, H. (1971) Analysis of the Self. New York: International Universities Press.

Moore, B.E. and Fine, B.D. (eds) (1990) Psychoanalytic Terms and Concepts. New Haven: Yale University Press.

Laplanche, J. and Pontalis, J.B. (1973) The Language of Psycho-analysis. London: Hogharth Press.

Linehan, M.M. (1997) Validation and psychotherapy. In Bohart, A.C. and Greenberg, L. (eds) Empathy Reconsidered: New Directions in Psychotherapy. Washington, D.C.: APA Press.

Macdonald, Keith M. (1995) The Sociology of the Professions. London: Sage.

MacMartin, C. (2008) Resisting optimistic questions in narrative and solution-focused therapies. In Peräkylä, A., Antaki, C., Vehviläinen, S. and Leudar, I. (eds) Conversation Analysis and Psychotherapy. Cambridge: Cambridge University Press.

Parsons, T. (1951) The Social System. Glencoe, IL: Free Press.

Peräkylä, A. (1995) AIDS Counselling: Institutional interaction and clinical practice. Cambridge: Cambridge University Press.

Peräkylä, A. (2004a) Reliability and validity in research based on naturally occurring social interaction. In Silverman, D. (ed.) Qualitative Research: Theory, Method and Practice. London: Sage.

Peräkylä, A. (2004b) Conversation analysis. In Seale, C., Silverman, D., Gubrium, J. and Gobo, G. (eds) Qualitative Research Practice. London: Sage.

Peräkylä, A. (2004c) Making links in psychoanalytic interpretations: a conversation analytic view, Psychotherapy Research, 14, 289-307.

Peräkylä, A. (2008) Conversation analysis and psychoanalysis: Interpretation, affect and intersubjectivity. In Peräkylä, A., Antaki, C, Vehviläinen, S. and Leudar, I. (eds) Conversation Analysis and Psychotherapy. Cambridge: Cambridge University Press.

Peräkylä, A. and Vehviläinen, S. (2003) Conversation analysis and the professional stocks of interactional knowledge, Discourse and Society, 14, 6, 727-50. 
Rogers, C.R. (1957) The necessary and sufficient conditions of therapeutic personality change, Journal of Consulting Psychology, 21, 2, 95-103.

Ruusuvuori, J. (2005) 'Empathy' and 'sympathy' in action: attending to patients' troubles in Finnish homeopathic and general practice consultations, Social Psychology Quarterly, 68, 3, $204-22$.

Ruusuvuori, J. (2007) Managing affect. Integration of empathy and problem solvining in health care encounters, Discourse Studies, 9, 5, 597-622.

Ruusuvuori, J. and Lindfors, P. (2009) Complaining about previous treatment in health care settings, Journal of Pragmatics, 41, 12, 2415-34.

Safran, J.D. and Segal, Z.V. (1990) Interpersonal Process in Cognitive Therapy. New York: Basic Books.

Sandler, J., Dare, C. and Holder, A. (1992) The Patient and the Analyst. The Basis of the Psychoanalytic Process. London: Karnac.

Schegloff, E.A. (2007) Sequence Organisation in Interaction: a Primer in Conversation Analysis. Cambridge: Cambridge University Press.

Sorjonen, M.L. (2001) Responding in Conversation: a Study of Response Particles in Finnish. Amsterdam: John Benjamins.

Vehviläinen, S. (2003) Preparing and delivering interpretations in psychoanalytic interaction, Text, $23,4,573-606$.

Vehviläinen, S., Peräkylä, A., Antaki, C. and Leudar, I. (2008) A review of the conversational practices of psychotherapy. In Peräkylä, A., Antaki, C., Vehviläinen, S. and Leudar, I. (eds) Conversation Analysis and Psychotherapy. Cambridge: Cambridge University Press.

Voutilainen, L., Peräkylä, A. and Ruusuvuori, J. (2010) Recognition and interpretation: responding to emotional experience in psychotherapy, Research on Language and Social Interaction, 43, 1, 85-107. 